Research Journal of Applied Sciences 5 (4): 285-302, 2010

ISSN: $1815-932 \mathrm{X}$

(C) Medwell Journals, 2010

\title{
Nature and Characteristics of Gold Mineralization at Al Abeidiya Area, Berber Province, Northern Sudan
}

\author{
${ }^{1}$ N.H. Lissan and ${ }^{2}$ A.K. Bakheit \\ ${ }^{1}$ Faculty of Earth Resources, China University of Geosciences, Wuhan, China \\ ${ }^{2}$ Department of Geology and Mining, College of Natural Resources, \\ University of Juba, Khartoum, Sudan
}

\begin{abstract}
The study integrates the results of field observations, petrographic investigations and wholerock/wall-rock alteration chemistry to emphasize the occurrence of gold mineralization at Al Abeidiya area, Northern Sudan and to determine its type and distribution, as well as the geological, mineralogical and geochemical controlling factors. The area is a regionally metamorphosed terrane underlain by crystalline Proterozoic basement complex comprising predominantly low to medium-grade, altered and polydeformed, calc-alkaline metavolcanic rocks and minor metasediments intruded by medium to high $\mathrm{K}$, calc-alkaline, metaluminous and I-type granitoidal batholiths that emplaced as volcanic arc plutonics above a Noeproterozoic subduction zone during the syn to late collision stages of crust evolution of the Nubian Shield. The study confirmed the existence of promising medium to high-grade gold mineralization (with content ranging between 0.01-24.0 g ton $^{-1}$ ) occurring as a shear zone-hosted, gold-quartz, gold-sulfide and disseminated gold formations in gold-bearing quartz veins, veinlets, sub parallel stringers and wall rock alteration zones. It is hosted by intensely sheared and hydrothermally altered granitoids and the surrounding greenschist-facies assemblages as well as, the ophiolitic sequences and controlled by post-batholithic brittle-ductile deformation with different intensity of shearing and hydrothermal alteration. Gold is preferentially encountered as fine to medium-grained native gold or as dispersed, tiny invisible grains associated with sulphides. Pyrite, arsenopyrite, sphalerite, chalcopyrite and minor galena, malachite, pyrrhotite and chalcocite are the sulfide phases associated with the gold, whereas iron oxide (limonite), carbonates (ankerite, siderite and calcite), chlorite and minor talc occur as gangue minerals. The country rocks locally suffered an extensive wall rock alteration that developed around the mineralized zones and encountered as; sericitisation, carbonatisation, chloritisation, pyritazation, silicification kaolinitisation and epidotization. Au-mineralization postdated metamorphism, older shearing/faulting events and batholithic intrusion and was synchronous with the latest stage of shear-induced deformation. The mineralization is interpreted as consistent with mesothermal type of hydrothermal deposits, where post-metamorphic and syn-deformation hydrothermal fluids ascending through channel ways within sheared zone leached elements from the metavolcanics and the nearby mafic/ultramafic rocks and precipitated in the host rocks. The credible energy sources for the hydrothermal activity that brought about the mineralization is likely unexposed intrusions at deeper levels within the shear zones.
\end{abstract}

Key words: Al Abeidiya gold discovery, gold mineralization, Umtrambiesh mine, mineral deposits N, gold of nubian shield, country rock

\section{INTRODUCTION}

Some domains within the Precambrian basement rocks of $\mathrm{N}$ and NE Sudan are well known as hosts for substantial gold mineralization occurring in different geological environments (Cottard et al., 1986; Vail, 1978; Klemm et al., 2001). A number of primary gold occurrences as well as placer gold deposits were identified from the Bayuda, Halfa, Gabgaba and the Red Sea terranes (e.g., Ed Duwishat, AbuSari, Umnabardi, Shammkhiya, Um Sarih, Wadi Singair, Gabeit, Ariab,
Aberkateib, Oyo, Micraff and Grabein mines, (Mageed, 1998, Fig. 1a). In spite of the region's long exploration history, there still many gold occurrences remain undiscovered due to inappropriate prospecting methods. Among theses is the Al Abeidiya gold mineralization, the subject of this paper which constitutes a new gold discovery within the above mentioned region. It lies some $56 \mathrm{~km}$ northeast of Atbara city in Berber Province, N Sudan, bounded between latitudes $18^{\circ} 11^{\prime}$ and $18^{\circ} 20^{\prime} \mathrm{N}$ and longitudes $33^{\circ} 55^{\prime}$ and $34^{\circ} 05^{\prime} \mathrm{E}$ (Fig. 1b).

Corresponding Author: N.H. Lissan, Faculty of Earth Resources, China University of Geosciences, P.O. Box 430074, Wuhan, China 


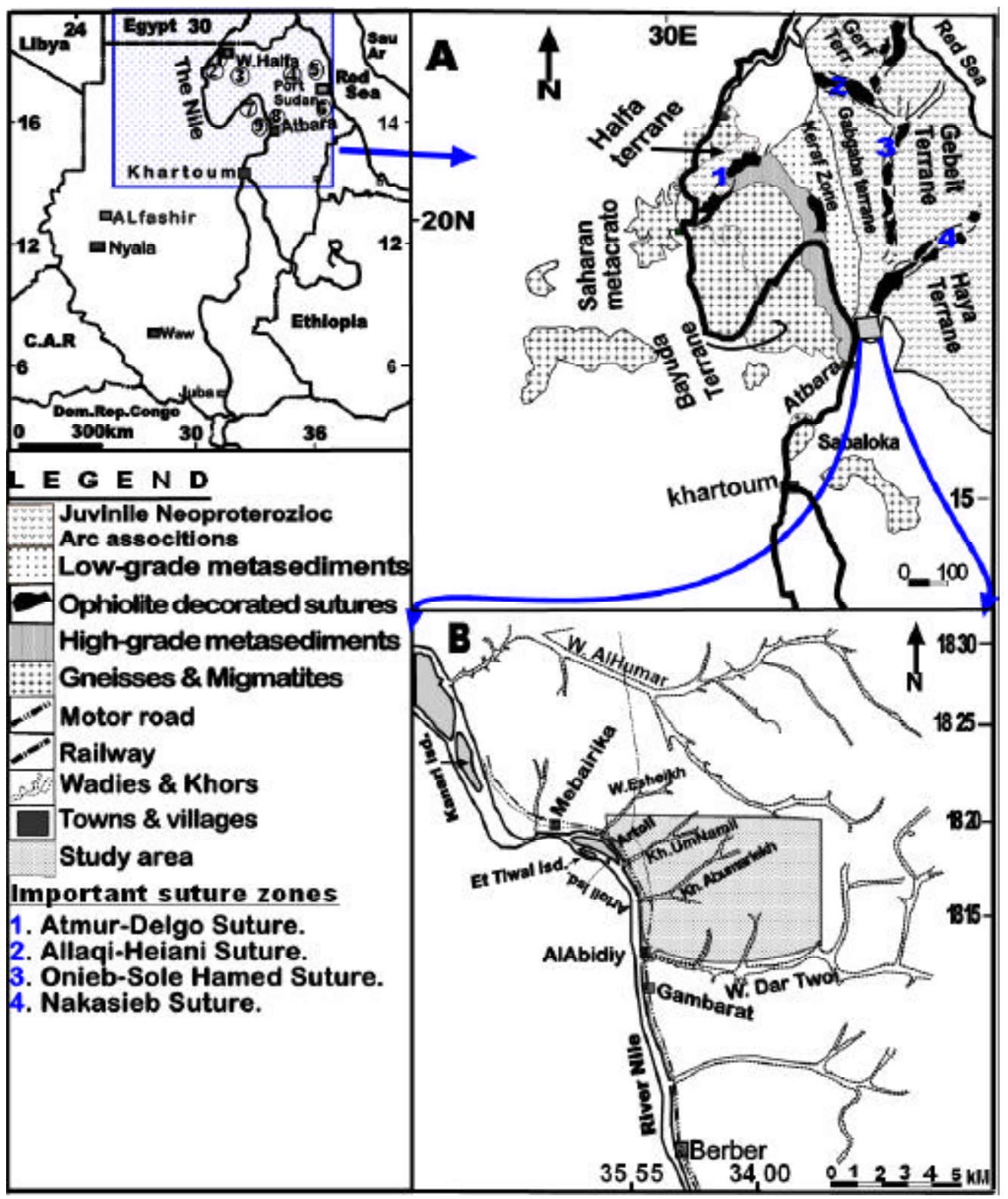

Fig. 1: Locality map for: (a) A part of NE Sudan showing major terranes and important suture zones, modified after Kuster and Liegeois (2001). Gold occurrences, (1) Duweishat, (2) Abu Sari, (3) Um Nabardi, (4) Abirkataeib, (5) Gebeit, (6) Ariab, (7) Shamkhiya, (8) Abeidiya, (9) Singgair-Um Sarih and (b) Al Abeidiya area

Gold mineralization in $\mathrm{N}$ and NE Sudan occurs in different styles corresponding to different geological environment and was genetically associated with magmatic cycles that repeatedly occurred in the region during different times (E1-Boushi, 1972; Bakhiet and Matheis, 1993; Elsamani et al., 2001). Most gold occurrences in the region linked to a hydrothermal activity that accompanied emplacement of ProterozoicEarly Paleozoic calc-alkaline granitoids (El-Shazly, 1957; Cottard et al., 1986; Vail, 1978). Some gold deposits were related to a shearing episode that post-dated emplacement of all batholithic intrusions and others are thought to have formed by exhalative hydrothermal processes during the break phases of sub-marine volcanic activity (Pohl, 1988; Bakheit, 1991).

Several attempts were made to classify gold occurrences in the region (Cottard et al., 1986; Aloub and Elsamani, 1991; Botros, 2004; Elsamani et al., 2001; Klemm et al., 2001) but the recently adopted classification is that based on mode of occurrence and nature of 
mineralization taking their tectonic evolution into consideration. In this classification, three broad categories of primary gold deposits were recognized in addition to the placer deposits:

- Pre-metamorphic mineralization (island-arc stage gold): Is a syngenetic gold mineralization associated with massive sulphides deposits that accompanied the calc-alkaline, island-arc volcanism. Gold mineralization in this type predated the regional metamorphism that affected the gneissic and volcano-sedimentary formations throughout the NE Sudan (some $715 \mathrm{Ma}$ ago)

- Gold mineralization related to the regional tectonometamorphic episodes (orogenic stage gold): Nonstratabound deposits formed during collisional orogeny, synchronous with regional metamorphism by different-sourced mineralizing fluids that remobilized gold and precipitated in silica-barite and massive barite formations, (possibly around $650 \mathrm{Ma}$ ). The deposits of this type are lithologically controlled and encountered mainly in both calc-alkaline I-type granitoids and metamorphic rocks surrounding them. Two varieties have been categorized: Gold collapse breccias which occur in the form of auriferous units that are essentially composed of silica, barite (was first recognized in the Ariab area and is referred to as silica barite rocks) and iron oxides. The gold mineralization that occurs in recrystallized host rocks close to sulfide minerals

- Gold mineralization related to shear zones (postcollision gold): This type of mineralization occurs exclusively in the form of auriferous quartz veins that developed along first and second-order shear fracture zones. In this type, gold was remobilized from volcano-magmatic sequences to be precipitated along structurally more favorable sites (at about $550 \mathrm{Ma})$

In this research, we integrated the results of field observations and petrographic investigations with whole-rock/wall-rock alteration chemistry in order to decipher the nature, type and distribution of newly discovered gold mineralization in the area and to determine the geological, mineralogical and chemical controlling factors of the deposit.

\section{REGIONAL GEOTECTONIC FRAMEWORK}

The area under consideration is a part of the Nubian Shield (NS) (Lissan and Bakiet, 2010) which is the northern sector of the East African Orogenic Belt (EAOB). The NS comprises a vast area of juvenile oceanic island arc crust extending from Sinai and Eastern Desert of Egypt, through the $\mathrm{N}$ and NE Sudan, into Eritrea, Ethiopia andSomalia (Stern and Kroner, 1993). This collision belt with its eastern part in Arabia (collectively known as the Arabian-Nubian Shield ANS) was formed near the end of the Neoproterozoic time when East and West Gondwana collided to form thesupercontinent of Gondwana (Kennedy, 1964; Kroner, 1984).

Although there still controversy persists on the evolution of the Arabian-Nubian Shield but it is generally accepted as an example of lateral crustal growth through subduction-related accretion processes that developed from an assembly of mostly intra-oceanic magmatic arc terranes with subordinate continental terranes (Gass, 1981; Kroner et al., 1987). In the recent widely accepted model proposed for the crustal evolution $\mathrm{f}$ the shield (Bentor, 1985; Stoeser and Camp, 1985; Kroner et al., 1987; Stern and Kroner, 1993; AbdelRahman, 1995) it thought to be evolved through the following four main stages:

Oceanic crust and island formation stage ( $\sim 950-850$ Ma): Stands for the first; 100 million years of the history of the ANS when island arc magmatism and juvenile crust formation operated. The stage began with suturing followed by sea-floor spreading and the initiation of subduction and ended in the formation of juvenile island arcs terranes. The stage represents the beginning of ocean-basin closure and Gondwana assembly.

Island arc terrains amalgamation stage ( $\sim 850-650 \mathrm{Ma})$ : The various arc terranes formed during the previous stage were welded together (microplate accretion) along ophiolite-bearing suture zones which let at the end to form the ANS. At the final phase of this stage $(\sim 670-650 \mathrm{Ma})$, the shield was subjected to several metamorphic episodes.

The batholithic stage $(\sim 650-580 \mathrm{Ma})$ : The amalgamation stage proceeded by widespread calc-alkaline magmatism, mainly of intermediate to felsic composition followed by continental collision and accretion against the Saharan Meta Craton (SMC) that marked the stabilization of the shield. The collision of the ANS with the SMC to the west occurred along N-trending arc-continental belt known as the Keraf Suture Zone (KSZ) at about $590 \mathrm{Ma}$ ago (Abdelsalam et al., 1998).

The KSZ is ophiolite-decorated, $500 \mathrm{~km}$ long and 30 $150 \mathrm{~km}$ wide, tectono-lithological structural belt (Vail, 1983, 1985; Abdelsalam and Stern, 1996; Abdelsalam et al., 1998). Towards the end of this stage ( $-600 \mathrm{Ma})$ a fundamental transition in tectonic style, from compressional to extensional occurred and ended with regional uplift and erosion. 
The post-orogenic stage ( $590-530$ Ma): Characterized by igneous activity representing late post-orogenic intracratonic and within-plate magmatism which formed granitoid plutons of mainly alkaline to peralkaline granites andesites, rhyolites and several episodes of dike swarms.

\section{GEOLOGICAL SETTING OF THE STUDY AREA}

The area is situated between the pre-Pan African high-grade gneissic terrane of the Bayuda Desert that belongs to the Saharan Metacraton in the west and the Neoproterozoic juvenile, accreted arc terranes of the Red Sea Hills that belong to the Nubian Shield in the east (Lissan and Bakiet, 2010). Geologically, it consists of a crystalline basement rocks comprising a series of spatially overlapping metamorphosed low-grade schistosed volcanics underlain by subordinate high-grade metasedimentary rocks. Both series are intruded by various generations of syn to late-orogenic calc-alkaline I-type granitoids and post-orogenic minor intrusions. The area is characterized by the occurrence of remnants of highly deformed and metamorphosed dismembered ophiolitic fragments. The basemen complex is covered locally in some parts, by Nubian sands and Recent superficial deposits (Lissan and Bakiet, 2010) (Table 1).

In this metamorphosed and deformed terrane, the contact relations among the basement rocks extensively modified by superimposed metamorphic and deformation events, hence, integration of obvious lithological difference, metamorphic extents, field appearance and structural styles besides petrographic and geochemical classification were used to classify the rock succession of the area into the following units:

High-grade metasedimentary rocks: This group constitutes the oldest rocks (Plaeproterozioc?) in the map area and is mainly concentrated in the western and northwestern parts as a local inlier in a narrow belt extending in N-S direction (Fig. 2). The sedimentary origin of these high-grade rocks is inferred in the field from the heterogeneous nature, frequent intercalation feature and the short-distance facie change. Obliteration by screes and alluvial deposits, besides the modification by superimposed deformation and metamorphic events

Table 1: Selected rock sample data from the study area

\begin{tabular}{|c|c|c|c|c|c|c|c|}
\hline \multirow[b]{2}{*}{ Samples } & \multicolumn{7}{|l|}{ Um Trambeish area } \\
\hline & Rock type & $\mathrm{Au}(\mathrm{ppb})$ & $\mathrm{Cu}(\mathrm{ppm})$ & $\mathrm{Zn}(\mathrm{ppm})$ & $\mathrm{Ag}(\mathrm{ppm})$ & As (ppm) & Mo (ppm) \\
\hline $\mathrm{UmT} 1$ & Quartz vein & 1790.00 & 124.00 & 290.00 & 5.00 & 9.0 & 3.0 \\
\hline $\mathrm{UmT} 2$ & Quartz vein & 8120.00 & 95.00 & 42.00 & 8.10 & 3.1 & 6.0 \\
\hline UmT3 & Granodiorite & 16.00 & 682.00 & 1.00 & $<0.30$ & 2.0 & 11.0 \\
\hline $\mathrm{UmT} 4$ & Sericite-chl schist & 11.00 & 961.00 & 873.00 & $<1.00$ & 5.0 & 2.0 \\
\hline UmT5 & Quartz vein & 24.00 & 36.00 & 6.00 & $<0.30$ & $<2.0$ & 23.0 \\
\hline UmT6 & Actinolite-schist & 7620.00 & 1175.00 & 2.80 & 6.70 & $<3.0$ & 2.0 \\
\hline $\mathrm{UmT} 7$ & Quartz vein & 49.00 & 1581.00 & 19.00 & $<0.30$ & 3.0 & 8.0 \\
\hline UmT8 & Quartz vein & 489.00 & 820.00 & 8.00 & 1.10 & 1.0 & 4.2 \\
\hline UmT9 & Quartz-mica schist & 136.00 & 890.00 & 47.00 & $<0.30$ & 7.0 & 3.5 \\
\hline UmT10 & Basic/ultra basic & 843.00 & 2892.00 & 90.00 & $<0.30$ & 3.0 & 9.8 \\
\hline UmT11 & Basic/ultra basic & 923.00 & 1256.00 & 2.00 & $<2.00$ & 1.6 & 30.0 \\
\hline UmT12 & Granodiorite & 8.00 & 139.00 & 1.00 & $<0.30$ & $<2.0$ & 29.0 \\
\hline UmT13 & Quartz vein & 1755.00 & 8.00 & 3.00 & 2.00 & 1.0 & 10.0 \\
\hline UmT14 & Sericite-chl schist & 11.00 & 47.00 & 32.00 & $<1.00$ & $<1.0$ & 2.4 \\
\hline UmT15 & Quartz vein & 1548.00 & 13.00 & 54.00 & 3.48 & 3.0 & 14.0 \\
\hline \multicolumn{8}{|c|}{ Artoli area } \\
\hline Ar1 & Quartz-diorite & 23.00 & 891.00 & 25.00 & 0.30 & 3.0 & 2.0 \\
\hline Ar2 & Granodiorite & 10.00 & 318.00 & 68.00 & 1.20 & 7.0 & 10.0 \\
\hline Ar3 & Sericite-chl schist & 3.00 & 480.00 & 76.00 & 27.00 & $<1.0$ & 9.2 \\
\hline Ar4 & Quartz vein & 9.00 & 32.00 & 0.90 & 1.00 & $<1.0$ & 5.1 \\
\hline Ar5 & Granodiorite & 2.00 & 1345.00 & 95.00 & 0.20 & 1.0 & 0.8 \\
\hline Ar6 & Diorite & 2.00 & 25.00 & 18.00 & 1.00 & 2.0 & 4.0 \\
\hline $\operatorname{Ar} 7$ & Quartz-mica schist & 3.00 & 193.00 & 30.00 & $<2.00$ & $<1.0$ & 30.0 \\
\hline Ar8 & Quartz vein & 2210.00 & 176.00 & 142.00 & 15.60 & 1.0 & 3.0 \\
\hline Ar9 & Sericite-chl schist & 4.00 & 7652.00 & 36.00 & 2.70 & $<1.0$ & 6.8 \\
\hline Ar10 & Actinolite- schist & 122.00 & 1650.00 & 8.00 & 4.80 & 5.0 & 23.0 \\
\hline Ar11 & Quartz vein & 1530.00 & 68.00 & 140.00 & 3.00 & 3.0 & 7.0 \\
\hline Ar12 & Gabbro & 61.00 & 345.00 & 135.00 & 17.00 & 6.0 & 4.0 \\
\hline Ar13 & Diorite & 3.00 & 23.00 & 16.00 & $<0.30$ & $<2.0$ & 8.5 \\
\hline Ar14 & Quartz vein & 1644.00 & 160.00 & 8.00 & 3.63 & 5.0 & 8.0 \\
\hline Ar15 & Quartz vein & 1276.00 & 27.00 & 3.00 & $<1.00$ & $<1.0$ & 6.0 \\
\hline
\end{tabular}


render sufficient field evidences for precise contact relations between this suite and the other groups to be detected. However, the suite everywhere studied in the region ascertained to be disconformably overlying high-grade gneisses and structurally overlain by Lowgrade volcano sedimentary series (El-Rabaa, 1976; Almond, 1982). The suite comprises variably interbedded lithologies of biotite-gneiss, quartzo-feldspathic gneiss, quartzite, marbles and amphibolites.

The gneissic unit is exposed along dry streams at the extreme western part as rather weathered surfaces concealed under variable thickness of sandstones, alluvial sands and lag deposits. The gneisses, in general are leucocratic to mesocratic, high to medium-grained rocks exhibiting detectible gneissic banding defined by parallel alignment of biotite and hornblende alternating with elongated quartz and plagioclase grains coinciding with the regional NW-SE trend. Pterographically, the gneiss composed of a simple mineral assemblage comprising angular to subangular quartz crystals within predominant orthoclase feldspars and minor plagioclase (Albite-oligoclase composition); both may be altered to turbid sericite and saussurite. Of the mafic minerals oriented yellowish brown biotite flakes by far exceed green prisms hornblende, muscovite, garnet and Fe-oxides. Secondary minerals of epidote, sericite and chlorite are commonly developed after mafic minerals, accessories of apatite, zircon, sphene and iron-oxides are also conspicuous.

Irregular bands and lenticular or tabular-shaped bodies of marbles and outstanding increased topographic ridges of quartzites are encountered in the eastern and the central parts of the map area.

Sporadic lens-shaped and patches of amphibole-rich rocks are observed in the NW part intercalating with the plutonic suite in a rather crosscutting relation and conformable with the adjacent metasediments. They are generally recognized by their dark to dark gray colour and medium-grained texture and commonly show megascopic preferred mineral segregation banding in accord with regional trend emphasized by preferred orientation of hornblende prisms and aligned felsic minerals. The amphibolites disclose granoblastic texture with preferred orientation of minerals which are hornblende, plagioclase and quartz as essentials, chlorite, epidote, serisite and biotite as secondary and sphene, apatite, zircon, iron oxides, garnet and pyrite as accessories ones.

The ophiolitic rocks: Abdel Rahman (1993) observed the occurrence of fragments of oceanic crust along generally NE-SW or NNE-SSW suture belts representing dismembered ophiolitic suite in the region including the study area. The occurrence of this suite is confirmed in the present study but is based merely on few insufficient filed observations as the suite mostly lies outside the mapped area.

The term ophiolitic suite used here refers to an integrated assemblage of altered rocks found a long pinching and swelling belt (thrust bounded sheared zone) within the low-grade sequence. They represented by carbonated and serpentinized ultramafic tectonic sequence (pyroxinite and peridoditre) and retrogressed cumulous metabasic rocks mainly gabbros and banded amphibolites accompanied by altered sheeted doleritic dykes, lavas and deep sea-water sediments (Phyllitic rocks, chert and iron-rich quartzite) which may represent scattered ophiolitic fragments.

The mentioned lithologies are neither found in one stratigraphic unit nor as pure compositional varieties. The mafic-ultramafic rocks are found at scattered localities southeast and east Umtrambiesh area as strongly altered rocks of talc, talc-chlorite and chlorite-actinolite schists and serpentinites. Sheeted dykes and lavas are of great scarcity, as only scattered minute lensiod pods of lava and very small and highly altered sheets of doleritic composition found just southeast the bend of Wadi Dar Tawai (Fig. 2).

Low-grade schistosed metavolcanics rocks: The group includes metamorphosed (up to green-schist facies conditions) predominantly basic to acidic metavolcanic rocks associated with minor sedimentary units encountered exposed in the neighborhood of Umtrambiesh ore field in addition to small sporadic outcrops in the granitoids plain to the north (Fig. 2).

This group of rocks usually has a gradational boundary with the underlying units and includes rocks that show varying degrees of deformation, ranging from massive, undeformed bodies to strongly schistosed rocks. Most of them are fine-grained with primary volcanic textures still recognizable (porphyritic and sometimes amygdaloid). Under the microscope, most rocks contain quartz, sericitized plagioclase, chlorite and actinolite, besides $\mathrm{K}$-feldspar, opaques, calcite and some rare relict pyroxene. This mineral assemblage and the shown textures are indicative features of green-schist facies metamorphism of originally volcanic rocks. Based on field, geochemical classification and petrographic data, theses schistosed rocks are classified into; quartz-mica schist, sericite-chlorite schist and actinolite-schist (Fig. 2). The metavolcanics are identified as sub-alkaline rocks carrying evolutionary trends of calc-alkaline affinity in a plate tectonic setting related to island arc environment (Fig. 3 and 4). 


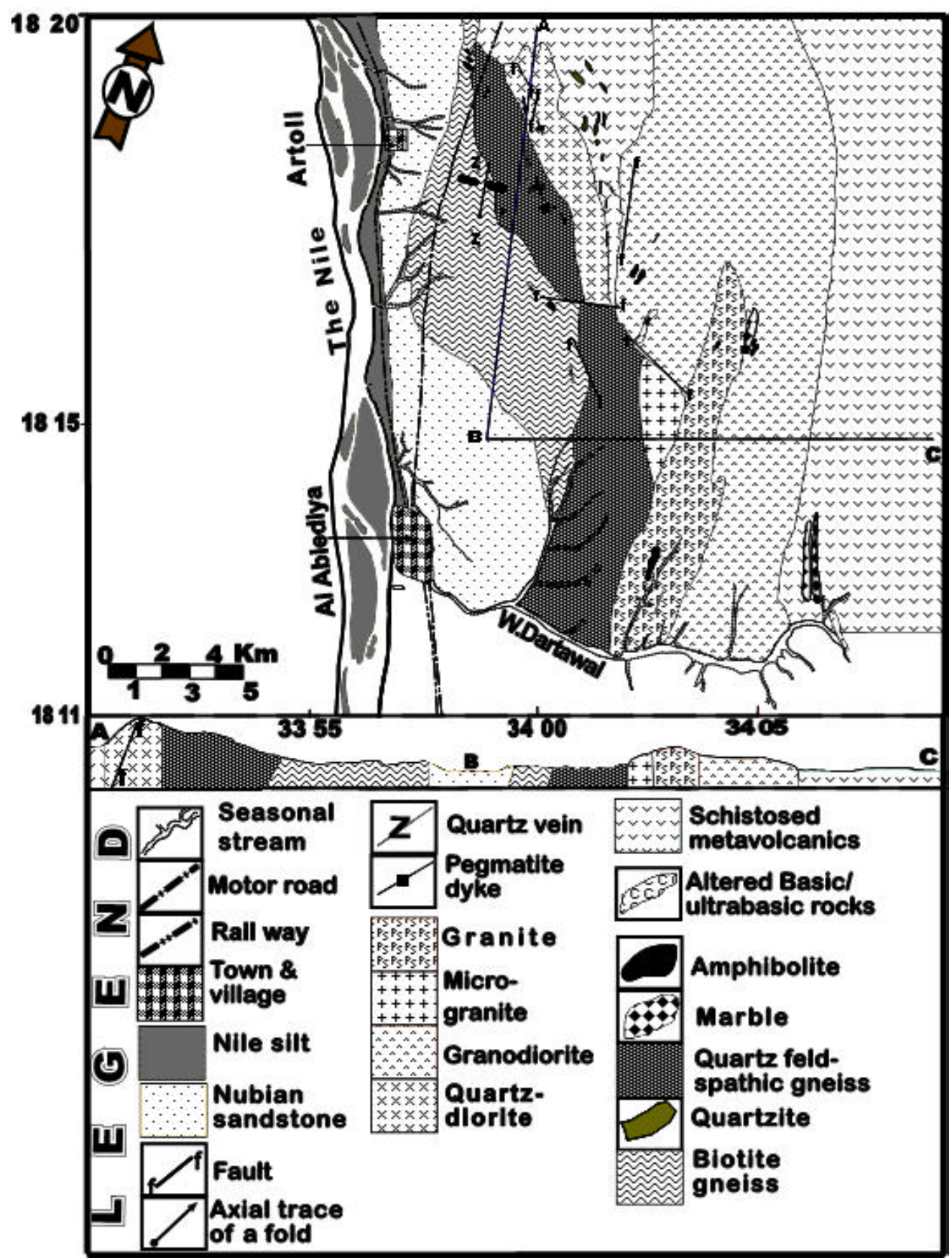

Fig. 2: Geological map of the study area

Syn to late-orogenic granitoid rocks: Vast masses of intermediate to acidic granitoids constitute a characteristic and dominant element of the basement rocks of the area, especially in the $\mathrm{N}$ and $\mathrm{NE}$ sectors where they form about $50 \%$ of the outcrops. Based on field, geochemical and petrographic evidences, they are generally range in composition from diorite, quartz diorite and granites to micro-granites but predominantly are hornblende granodiorites. The suite is believed to be a product of larger plutons of syn to late orogenic igneous activities in the late Proterozioc time that have been emplaced in both the high and low-grade sequences as evident from their xenolithic contents.

Diorite, quartz diorite and granodiorite constitute a wide range of rocks that occur as excellent exposures of low to moderate relief in N, NE and central parts of area. 

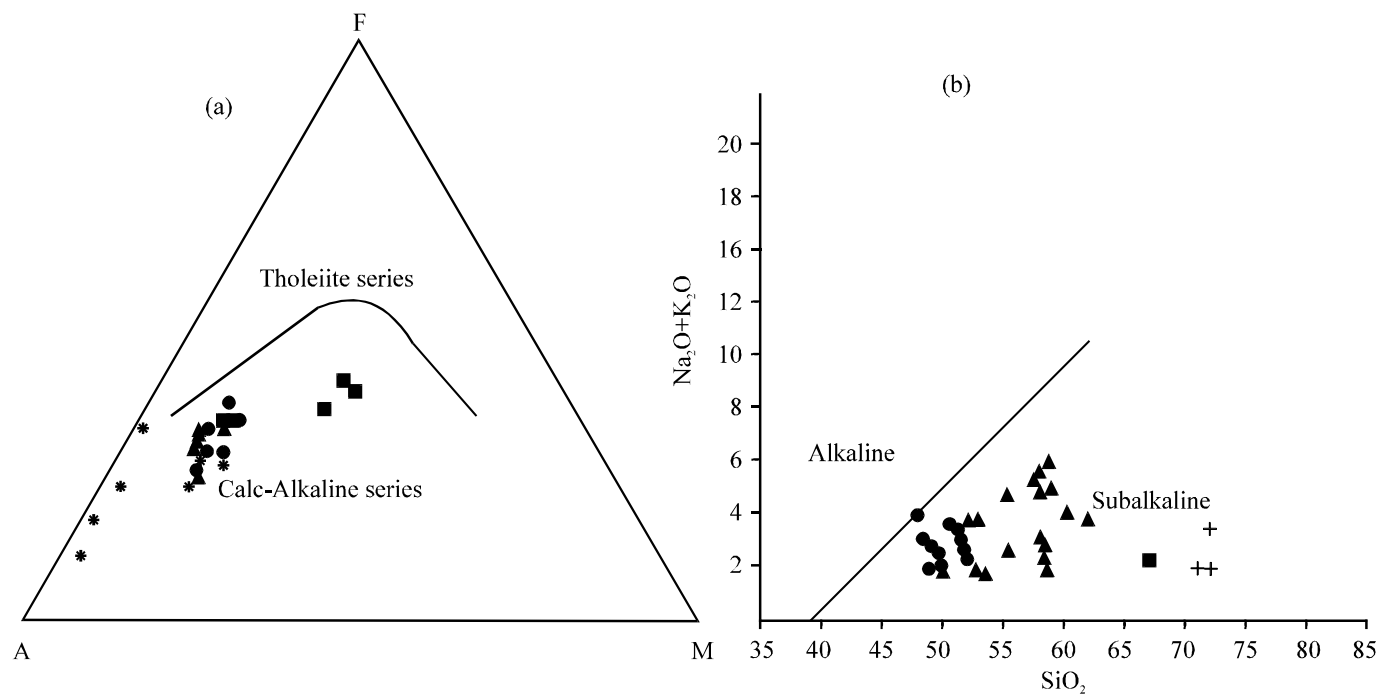

Fig. 3: (a) AFM diagram for AL Abeidiya granitoids and (b) The silica versus total alkali plot for AL Abeidiya Metavolcanics (Series boundaries after Irvine and Barager, 1971). (Symbols (a) Plutonics: Closed triangle green Quartz-diorite, closed circle deep brown Granodiorite, closed cubic blue $\approx$ Diorite and cross star red $\approx$ granite and (b) Metavolcanics: Closed triangle red ${ }^{\sim}$ Basalt, closed circle blue ${ }^{\sim}$ Andesite, closed cubic box green $\approx$ Dacite and cross pink $\approx$ Rhyodacite)

(a)

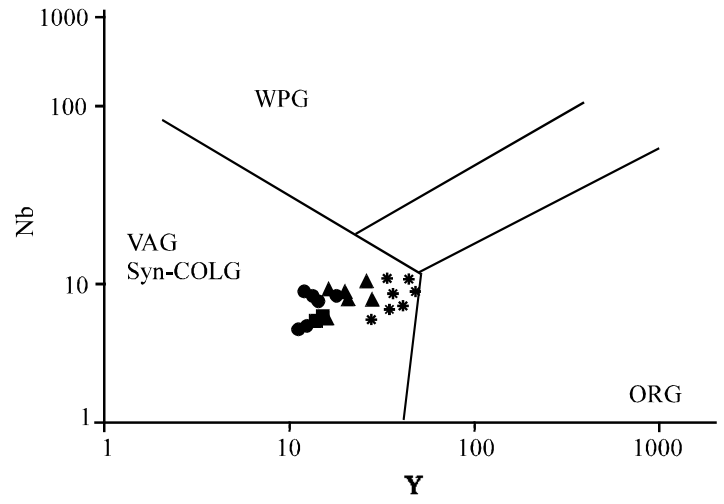

(b)

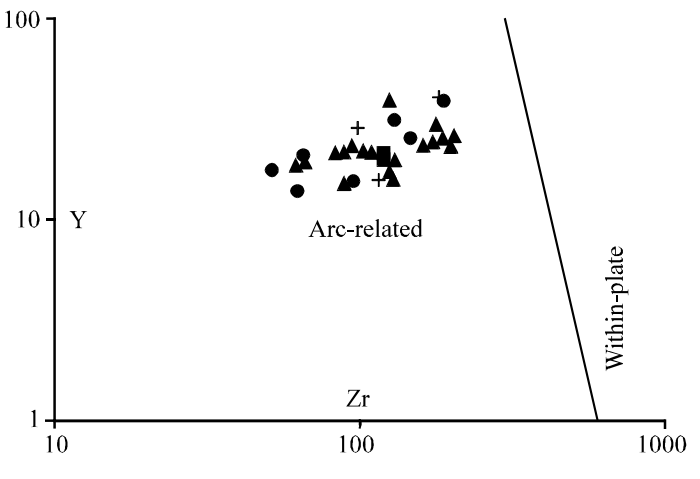

Fig. 4: (a) Y vs. $\mathrm{Nb}$ (in ppm) discrimination digram, (Pearce et al., 1984) for deciphering the tectonic setting of the AL Abeidiya granitoids. $\mathrm{ORG}=$ Ocean Ridge Granites, Syn-COLG $=$ Syn-Collisional granites, $\mathrm{VAG}=$ Volcanic Arc Granites, WPG $=$ Within Plate Granites and (b) Zr vs. Y Biaxial geochemical discrimination diagram indicating the subduction-arc features for AL Abeidiya Metavolcanics (Muller et al., 2001) (Symbols: as in Fig. 3)

They are coarse to medium-grained, gray to grayish dark in colour and mostly altered and deformed types to the extent that gradations from the moderately massive to a slight banding exist. Microscopic observation revealed coarse hypidiomorphic textures and disclosed mineral phases of altered (to sericite and chlorite) plagioclase, pleochoric prisms of hornblende oriented pale to dark-brown pleochoric biotite, quartz, sericitized and discontinuously zoned $\mathrm{k}$-feldspar, perthites in addition to accessory sphene, zircon, apatite, pyrite and magnetite and secondary minerals of sericite, chlorite, epidote, carbonates and kaolin. Granites and few micro-granites constitute only minor phases within the granodiorite sequence and believed to be emplacement products of the last intrusion phase to which the area was subjected. Under the microscope, they show a porphyritic texture formed by pink K-feldspar phenocrysts in affine cloudy quartz and feldspar matrix associated with lesser amount of mafic minerals; sub-hedral flakey, brown biotite, green hornblende, chlorite, epidote and sericite and accessories of zircon, apatite and iron oxides. 


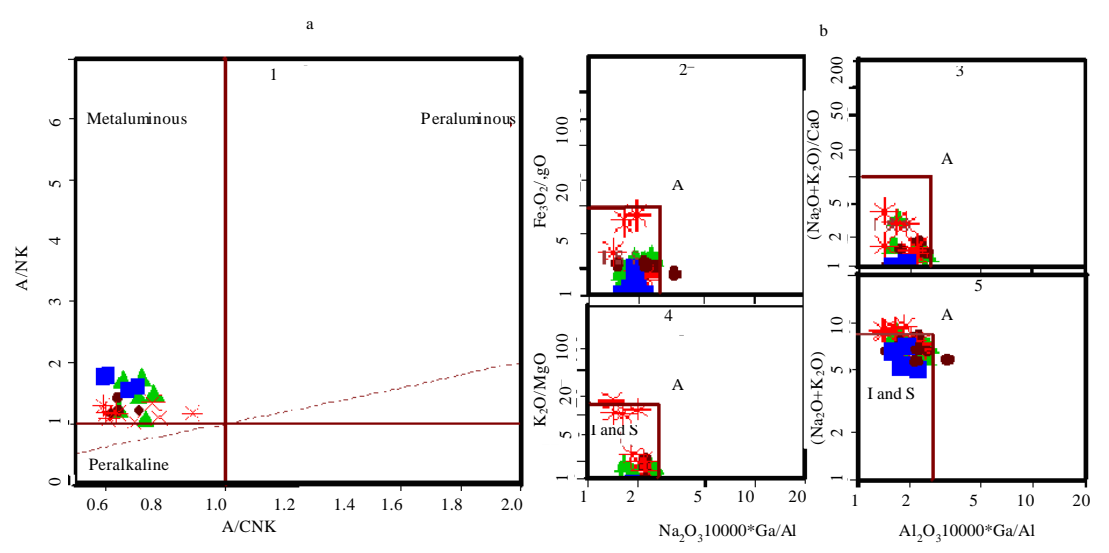

Fig. 5: (a) $\mathrm{A} / \mathrm{CNK}=\mathrm{Al} 2 \mathrm{O} 3 /\left(\mathrm{CaO}+\mathrm{Na}_{2} \mathrm{O}+\mathrm{K}_{2} \mathrm{O}\right)$ vs. $\mathrm{A} / \mathrm{NK}=\mathrm{Al} 2 \mathrm{O} 3 /\left(\mathrm{Na}_{2} \mathrm{O}+\mathrm{K}_{2} \mathrm{O}\right.$ mol.\%) diagram of Shand (1927) discriminating metaluminous, peraluminous and peralkaline compositions and (b) Set of binary plots; $10000 \mathrm{Ga} / \mathrm{Al}$ vs. $\mathrm{K}_{2} \mathrm{O}+\mathrm{Na}_{2} \mathrm{O},\left(\mathrm{K}_{2} \mathrm{O}+\mathrm{Na}_{2} \mathrm{O}\right) / \mathrm{CaO}, \mathrm{K}_{2} \mathrm{O} / \mathrm{MgO}$ and $\mathrm{Fe}_{2} \mathrm{O}_{3} / \mathrm{MgO}$ ? proposed by (Whalen et al., 1987) to distinguish A-type granitoids from I- and S-types (Major elements in in wt \% and trace and REE in ppm) (Symbols: as in Fig. 3)

The granitoids are medium to high $\mathrm{K}$, calc-alkaline, metaluminous and I-type suite emplaced as volcanic arc granites above a Noeproterozoic subduction zone during the syn to late collision stages of crust evolution (Fig. 4 and 5). The magmas of these granitoids are thought to be derived from the mantle with involvement of minor crust components.

Post-orogenic minor intrusions: Commonly numerous quartz veins and lesser amounts of pegmatitic bodies together with scarce acidic and basic dykes, associated alteration features are observed invading the country rocks suggesting an intense hydrothermal activity throughout the area.

The pegmatites are very coarse-grained massive rocks made up essentially of aggregates of very coarse crystals of alkali-feldspar (orthoclase and microcline), quartz, some plagioclase, few mica flakes tourmaline and apatite.

A number of scattered acidic and basic dykes are found cutting the different units of the basement complex. The dykes are generally short narrow bodies $(0.5-1.0 \mathrm{~m}$ in width and rarely traceable for more than $3 \mathrm{~m}$ ) occurring in contrast colour with host rocks. Lithologically, typical granitic dykes (aplitic and granophyric) predominate, though dark and fine-grained basic dikes are also present. The acidic dykes are fine-grained, white to pale pinkish rocks and show equigranular textures. They contain quartz, K-feldspar, variably altered plagioclase and biotite flakes.

The quartz veins represent an important episode in the history of the area since emplacement of some veins was connected with the hydrothermal activities that brought about the gold mineralization. They are of variable sizes ranging from stringers, pods and narrow veins up to wide ones. A close examination revealed existence of overprinting relationships between veins, replacement, ribbon and serrate structures, intermingled quartz veinlets and altered wallrocks suggesting multiple stages of ore deposition and more than a generation of quartz veins in the area, the following are observed:

The first generation: Constitutes old, least abundant, $\mathrm{cm}$ to m-scale, NNW-SSE trending, highly deformed and gold-bearing quartz veins characterized by pinch and swell and bifurcation features. It found forming a linear fabric in the host rocks semi-concordant with their regional trend. This type seems to be introduced along structures, older shear zones and wall rock alteration zones during an early stage of D3 deformation phase.

The second generation: Comprises N-S trending widespread veins that are mainly concordant, deformed and folded with enclosing rocks; found stretched parallel to the D3 structures or as veinlets in and adjacent to D3 shear zones. Individual quartz veins vary from a few $\mathrm{cm}$ up to $1.5 \mathrm{~m}$ wide and $<1 \mathrm{~m}->200 \mathrm{~m}$ long. The veins of this type exhibit varying colours, white, grey, smoky, yellowish, brown, reddish or stained greenish depending on weather the quartz is pure, contaminated or stained by iron oxides or malachite. The veins usually pinch, swell, bifurcate into small veins, veinlets and stringers and are associated with the main gold mineralization in Umtrambiesh area where they observed accompanied by conspicuous carbonates, tourmaline, pyrite and chalcopyrite. 
The third generation: Represents a younger phase of less abundant veins with wider dimensions compared with the former ones, found truncating the other generation in NW-SE direction and occur as discontinuous, crashed and patchy bodies in brittle fractures. Quartz veins were emplaced at shallower crustal levels during the brittle reactivation of the strike-slip shear zones. This type of veins is often barren massive veins consisting of milky to whitish clean quartz and some tourmaline crystals.

The sedimentary cover (Mesozoic-recent): Sedimentary rocks assigned to the formal Nubian Sandstone Formation occur in the area as local outlier chiefly confined to a narrow land-strip stretched parallel to the eastern bank of the Nile. Most surface spreads of the formation are deeply covered with superficial deposits and loose rock screes.

The sediments as else where in he country, comprise undeformed, unmetamorphosed and bedded fluvial to fluvo-deltaic sequence that uncomfortably overlie the basement complex in a flat-lying attitude (Omer, 1983). Field and petrography revealed that the greater bulk of these sediments consist of medium to coarse-grained and variously cemented sandy facies of multi-colour (white, gray, dark, yellowish and brown), the coarser verities are always occupy the basal parts in fining upward sequence with rare true conglomerates.

Recent/Pleistocene superficial deposits uncomfortably overlie the above sediments and the underlying basement rocks. Gray to grayish dark heavy overburden of sandy clay and silty mud cover the Nile islands and the flood plains bordering it. The present-day beds of the dried-up steams have their floors covered by thin reddish to dark grayish loams and sandy clays of flush plain type mostly, coarse remnants of water-worn sediments comprising sub-angular to sub-rounded gravels.

\section{STRUCTURAL SETTING}

The study area conspicuously went through a multistage deformation history as shown by the several overprinted folding, NW-SE striking foliation, N-S and NW-SE striking shear zones and N to NNE strike faulting that observed in different localities of the area. Although, the structural setting of the area is not yet been fully resolved in this study but convincing evidences of polydeformation features, within which at least three phases named D1-D3 are recognized.

D1 structures: D1 phase deformational features are the oldest structural feature recognized in the area. They were reported from the high-grade metasediments as small scale tight to isoclinal, E and ENE striking folds thought to be associated with early collisional stages. Development of E-striking, steeply N-dipping axial plane cleavage fabrics (S1) which are folded by younger subsequent D2 and D3-related structures, characterize D1 folds.

D2 structures: Structures generated during D2 deformation represent the main structural features recognized in the entire area. They are preserved mainly as mesoscopic-scale folds within the low-grade, island arc volcano-sedimentary rocks (likely formed during the emplacement of mafic-ultramafic rock assemblages). D2 deformation generated dominantly N-S striking, tight to open folds, thrusts shear zones and well-developed N-dipping, axial planar cleavage S2 chistosity which represent the main planar fabrics observed in the entire area.

D3 structures: D3 represent structures associated with the latest brittle-ductile phase of deformation that accompanied the latest stages of collision (Abdelsalam and Stern, 1996). Development of large and mesoscopic scales, NNW-SSE and NS trending open folds, N-S and NW-SE striking brittle ductile shear zone and reactivation of some of the thrust faults, characterize D3 phase.

D3 structures are superimposed over D1 and D2 folds and produced S3 schistosity of SW-verging axial planar cleavages which intersect S1 and S2 foliations. Gold bearing quartz veins and alteration zones in the study area are located within D3 shear zones. Shear zones in the area are defined by zones of fine-grained country rocks characterized by increasing density of schistosity and foliation planes (Fig. 6a, b) and commonly contain closely spaced quartz veins which are parallel to the strike of the shear zones.

Two types of shear structures were recognized; the dominant N-S striking ductile shear zone and subordinate younger NW-SE trending brittle ductile structures. N- to NNE-trending strike-slip faults cut the country rocks of the area. They post-date D1 and D2 deformations, second generation quartz-veins and the mineralization and might be synchronous with the latest D3 phase (Fig. 7).

\section{ANALYTICAL METHODS}

The study was carried out using fieldwork and laboratory investigations. The fieldwork was executed through detailed geo-traverses during tow field trips that collectively lasted for 7 weeks on November and January of 2005. During this fieldwork, the lithology, 

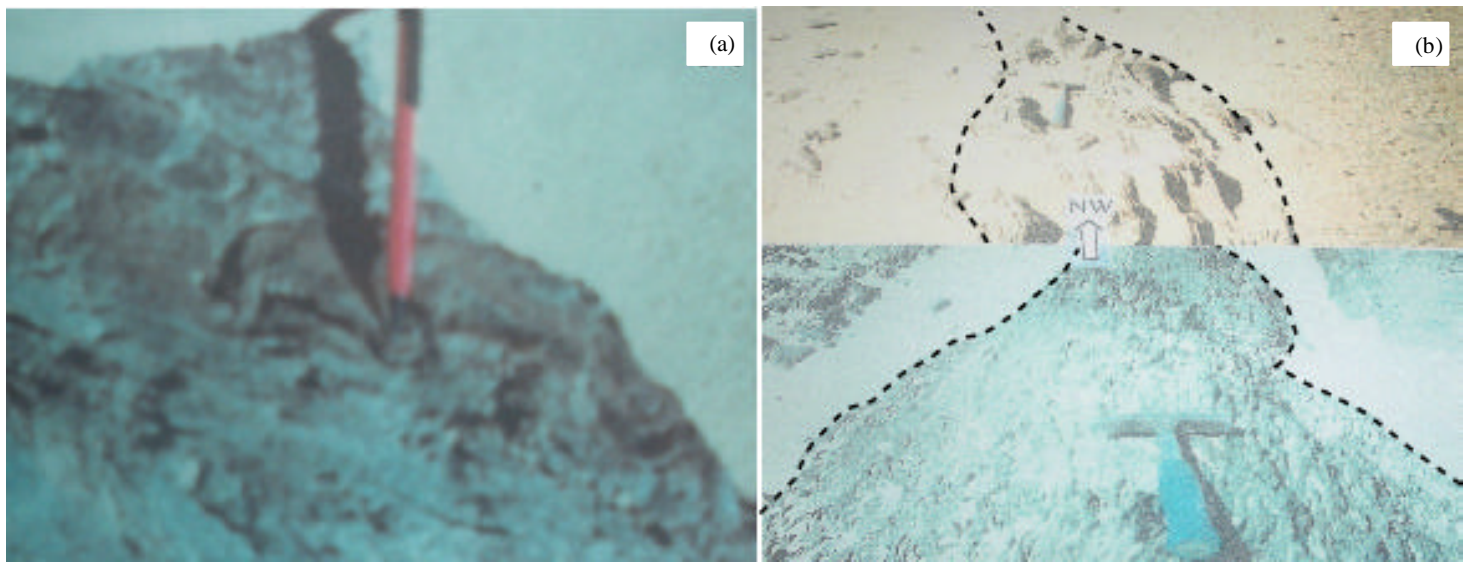

Fig. 6: (a) D2 folds from the low-grade metavolcanic showing S2 foliations crenulate S1 foliations and (b) Shearing effects on schistosed rocks from Artoli area

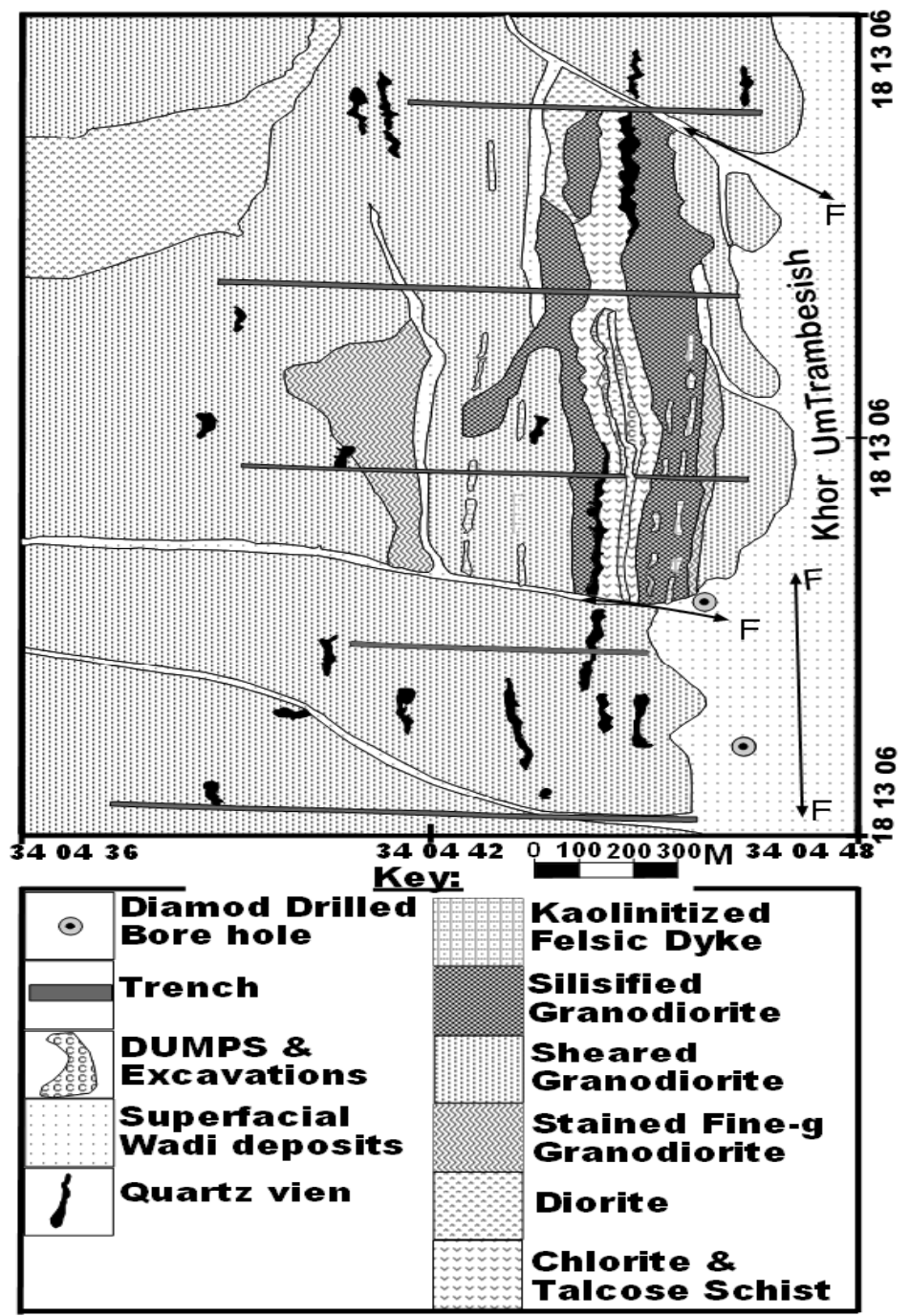

Fig. 7: Geological sketch map of Umtrambiesh Mining Area 
mineralization, quartz veins and alteration intensity of the rocks were studied using high magnification lenses, in addition to systematic structural measurements that were carried out to reveal field relations. About 145 scattered random surface samples, besides channel and core samples from trenches and diamond drill holes (dug by The Rida Mining Company RMC) were collected for petrographic and geochemical investigations. The samples are representative samples encompassing the compositional and spatial ranges of unaltered host rocks, zones of different intensities of shearing, hydrothermal alteration and mineralized quartz veins.

These field studies were followed up with detailed petrographic studies in which rock types and structural associations were verified. A number of thin and polished sections were prepared at the laboratories of Geological Research Authority of Sudan (GRAS) and at the Department of Geology, University of Khartoum and were investigated under a normal petrographic microscope to reveal the mineralogical composition, textural and microstructural features, degree of alteration and metasomatism. Consequently, 97 samples were petrographically selected for whole-rock chemical analyses and submitted through Rida Mining Company, Sudan to the ACME Analytical Laboratories, Vancouver, Canada for analytical work and calibration against international standards. The final analytical results of only some selected samples are shown in Table 2 and 3.

Whole rock element compositions were determined using inductively coupled plasma-atomic emission spectroscopy (ICP-ES) technique at ACME Analytical Laboratories, after lithium metaborate/tetraborate fusion and dilute nitric acid digestion of rock powder. Replicate analyses for some major and trace elements for some key samples were carried out by X-ray fluorescence spectrometry technique (XRF) following standard techniques and using a Phillips Venus $200 \mathrm{XRF}$ instrument at the analytical laboratories of the Geological Research Authority of the Sudan (GRAS).

Table 2 : Element correlation matrix for analyzed samples from the study area

\begin{tabular}{|c|c|c|c|c|c|c|c|}
\hline Elements & Mo & $\mathrm{Cu}$ & $\mathrm{Zn}$ & $\mathrm{Ag}$ & $\mathrm{Co}$ & $\mathrm{As}$ & $\mathrm{Au}$ \\
\hline Mo & 1.00 & 0.41 & 0.04 & 0.22 & 0.13 & 0.38 & 0.14 \\
\hline $\mathrm{Cu}$ & 0.41 & 1.00 & 0.45 & 0.30 & 0.60 & 0.90 & 0.14 \\
\hline $\mathrm{Zn}$ & -0.04 & 0.45 & 1.00 & 0.25 & 0.80 & -0.08 & -0.58 \\
\hline Ag & 0.22 & 0.03 & 0.25 & 1.00 & 0.14 & -0.39 & -039.00 \\
\hline $\mathrm{Co}$ & 0.13 & 0.60 & 0.80 & 0.14 & 1.00 & 0.19 & -059.00 \\
\hline As & 0.38 & 0.09 & -0.08 & -0.39 & 0.19 & 1.00 & 0.99 \\
\hline $\mathrm{Au}$ & 0.36 & 0.54 & -0.14 & -0.39 & 0.11 & 0.99 & 1.00 \\
\hline
\end{tabular}

Table 3 : Major elements variations of selected rocks from different alteration zones within the study area

\begin{tabular}{|c|c|c|c|c|c|c|c|c|c|c|c|c|c|c|c|c|c|c|c|}
\hline \multirow{2}{*}{\begin{tabular}{l} 
Zone \\
\hdashline$-\cdot-$ \\
Sample \\
\end{tabular}} & \multicolumn{6}{|c|}{ Least-altered host rocks } & \multicolumn{4}{|c|}{ Outer alteration zone } & \multicolumn{5}{|c|}{ Intermediate alteration zone } & \multicolumn{4}{|c|}{ Inner alteration zone } \\
\hline & $\mathrm{Ga} 4$ & $\mathrm{D} 2$ & QD2 & GD4 & $\mathrm{G} 2$ & $\mathrm{Ga} 2$ & QD3 & GD3 & G1 & $\mathrm{Ga6}$ & D5 & QD2 & GD2 & G3 & Ga5 & $\mathrm{D} 4$ & QD2 & GD3 & G6 \\
\hline $\mathrm{iO}_{2}$ & 49.33 & 58.22 & 69.70 & 68.210 & 72.06 & 47.33 & 66.850 & 64.40 & 71.76 & 46.57 & 57.19 & 67.65 & 59.240 & 70.33 & 46.52 & 55.84 & 64.24 & 61.55 & 69.12 \\
\hline $\mathrm{TiO}_{2}$ & 0.89 & 0.62 & 0.20 & 0.340 & 0.15 & 1.05 & 0.410 & 0.64 & 0.17 & 0.67 & 1.82 & 0.61 & 0.660 & 0.30 & 0.45 & 1.82 & 1.10 & 1.92 & 0.39 \\
\hline $\mathrm{Al}_{2} \mathrm{O}_{3}$ & 17.05 & 13.14 & 13.80 & 12.630 & 12.45 & 13.01 & 14.560 & 13.18 & 13.30 & 8.78 & 13.11 & 13.46 & 15.690 & 14.06 & 9.45 & 11.30 & 13.00 & 16.53 & 11.15 \\
\hline $\mathrm{e}_{2} \mathrm{O}_{3}$ & 10.17 & 7.91 & 3.35 & 4.480 & 1.54 & 10.71 & 4.270 & 5.81 & 4.23 & 11.02 & 8.37 & 4.27 & 7.130 & 5.16 & 11.71 & 10.70 & 6.43 & 7.15 & 6.24 \\
\hline $\mathrm{AnO}$ & 0.19 & 0.09 & 0.10 & 0.190 & 0.05 & 0.25 & 0.200 & 0.43 & 0.05 & 0.26 & 0.10 & 0.20 & 0.530 & 0.06 & 0.26 & 0.21 & 0.23 & 0.61 & 0.12 \\
\hline $\mathrm{AgO}$ & 7.71 & 6.35 & 1.92 & 3.990 & 1.17 & 5.11 & 520 & 3.34 & 0.45 & 2.86 & 5.53 & 1.52 & 50 & 0.42 & 2.81 & 4.45 & 1.44 & 2.88 & 0.37 \\
\hline $\mathrm{CaO}$ & 10.35 & 6.76 & 5.43 & 4.860 & 6.27 & 10.00 & 6.110 & 4.65 & 2.42 & 9.51 & 6.53 & 7.51 & 3.760 & 1.18 & 8.15 & 5.86 & 4.96 & 2.25 & 5.43 \\
\hline $\mathrm{a}_{2} \mathrm{O}$ & 3.11 & 3.93 & 3.85 & 3.740 & 3.93 & 3.68 & 3.700 & 4.10 & 4.43 & 4.01 & 3.83 & 2.43 & 4.730 & 4.21 & 4.03 & 3.94 & 2.26 & 1.67 & 4.57 \\
\hline $\mathrm{K}_{2} \mathrm{O}$ & 0.29 & 1.13 & 0.94 & 1.190 & 2.12 & 0.38 & 1.150 & 1.33 & 2.32 & 0.42 & 2.19 & 1.25 & 1.530 & 3.53 & 0.45 & 2.22 & 1.70 & 1.67 & 0.67 \\
\hline${ }_{2} \mathrm{O}_{5}$ & 0.38 & 0.13 & 1.30 & 0.050 & 0.13 & 0.49 & 0.140 & 0.15 & 0.14 & 0.56 & 0.25 & 0.14 & 0.180 & 0.17 & 0.66 & 0.12 & 1.16 & 0.36 & 0.19 \\
\hline OI & 0.70 & 0.50 & 0.40 & .200 & 0.40 & 7.90 & 1.100 & 2.40 & 0.80 & 15.50 & 1.00 & 1.20 & 3.900 & 1.10 & 16.00 & 4.00 & 4.00 & 3.60 & 1.80 \\
\hline Total & 100.20 & 99.86 & 100.90 & 100.900 & 100.30 & 99.91 & 100.000 & 100.40 & 100.00 & 100.20 & 99.92 & 100.24 & 100.600 & 100.52 & 100.49 & 100.46 & 100.52 & 100.19 & 100.05 \\
\hline Sample & $\mathrm{Ba} 2$ & An18 & $\mathrm{Da} 25$ & $\mathrm{Rd} 21$ & Ub13 & $\mathrm{Ba} 2$ & An1 & $\mathrm{Da} 3$ & $\mathrm{Rd} B$ & Ub26 & $\mathrm{Ba} 2$ & $\operatorname{An} 22$ & Da28 & $\mathrm{Rd} 27$ & Ub5 & $\mathrm{Ba} 2$ & An1 & Da8 & Ub6 \\
\hline $\mathrm{SiO}_{2}$ & 52.19 & 62.16 & 68.13 & 71.00 & 46.00 & 49.55 & 60.55 & 67.00 & 71.78 & 45.00 & 48.55 & 58.10 & 66.13 & 69.56 & 43.70 & 46.00 & 54.15 & 59.29 & 42.33 \\
\hline $\mathrm{TiO}_{2}$ & 0.27 & 0.12 & 0.18 & 0.42 & 0.22 & 0.36 & 0.16 & 0.19 & 0.56 & 0.65 & 0.58 & 1.35 & 0.21 & 0.78 & 1.09 & 0.63 & 1.92 & 0.49 & 1.22 \\
\hline $\mathrm{Al}_{2} \mathrm{O}_{3}$ & 12.14 & 13.16 & 10.27 & 11.96 & 11.89 & 13.16 & 15.55 & 12.39 & 9.93 & 17.04 & 64 & 14.45 & 10.27 & 14.19 & 15.10 & 12.14 & 15.53 & 16.47 & 14.02 \\
\hline $\mathrm{e}_{2} \mathrm{O}_{3}$ & 12.13 & 6.49 & 6.64 & 6.14 & 6.98 & 13.10 & 8.48 & 7.45 & 7.36 & 10.21 & 13.77 & 9.16 & 7.64 & 8.45 & 11.60 & 13.75 & 10.92 & 7.92 & 13.00 \\
\hline $\mathrm{MnO}$ & 0.16 & 0.11 & 0.13 & 0.03 & 0.12 & 0.16 & 0.12 & 0.33 & 0.08 & 0.17 & 0.22 & 0.12 & 0.34 & 0.13 & 0.17 & 0.25 & 0.17 & 0.36 & 0.86 \\
\hline $\mathrm{AgO}$ & 12.26 & 4.19 & 4.23 & 1.33 & 14.88 & 12.23 & 0.66 & 4.13 & 0.39 & 8.23 & 11.97 & 3.15 & 3.23 & 0.37 & 7.29 & 11.65 & 2.98 & 2.24 & 7.72 \\
\hline $\mathrm{CaO}$ & 8.89 & 6.67 & 7.60 & 6.31 & 14.63 & 8.37 & 5.25 & 6.19 & 6.44 & 10.59 & 7.66 & 4.35 & 6.61 & 1.10 & 11.71 & 7.17 & 4.27 & 6.12 & 11.70 \\
\hline $\mathrm{Na}_{2} \mathrm{O}$ & 0.09 & 4.37 & 0.79 & 0.50 & 0.26 & 1.65 & 4.75 & 0.89 & 1.11 & 1.53 & 1.88 & 5.30 & 1.00 & 2.23 & 1.17 & 1.55 & 5.89 & 3.19 & 1.20 \\
\hline $\mathrm{K}_{2} \mathrm{O}$ & 0.90 & 1.65 & 0.25 & 1.45 & 0.06 & 0.14 & 2.53 & 0.50 & 0.06 & 0.31 & 0.19 & 1.48 & 0.85 & 1.48 & 0.11 & 0.20 & 1.89 & 1.40 & 0.02 \\
\hline $\mathrm{P}_{2} \mathrm{O}_{5}$ & 0.60 & 0.30 & 0.17 & 0.08 & 0.15 & 0.70 & 0.17 & 0.14 & 0.09 & 0.27 & 0.81 & 0.34 & 0.87 & 0.09 & 0.34 & 0.22 & 0.39 & 0.93 & 0.33 \\
\hline LOI & 1.00 & 1.20 & 1.60 & 0.50 & 5.00 & 1.20 & 1.70 & 1.50 & 1.80 & 5.40 & 6.59 & 2.30 & 2.00 & 2.00 & 7.70 & 7.00 & 2.20 & 1.90 & 7.90 \\
\hline Total & 100.60 & 100.40 & 100.00 & 99.72 & 100.20 & 100.60 & 99.92 & 100.70 & 99.60 & 99.40 & 100.90 & 100.10 & 99.20 & 100.40 & 100.00 & 100.56 & 100.30 & 100.30 & 100.30 \\
\hline
\end{tabular}


All major element values used in plots were recalculated to $100 \%$ on an anhydrous basis. Loss On Ignition (LOI) was determined from total weight loss after repeated ignition of the powdered samples at $1000^{\circ} \mathrm{C}$ for $1 \mathrm{~h}$ and cooling. Satisfying analytical accuracy was achieved by using replicate analyses and comparing with rock standards.

\section{GOLD MINERALIZATION IN THE AREA}

Occurrence of gold mineralization: Although, gold mining activities in the $\mathrm{N}$ and $\mathrm{NE}$ Sudan has a long history (it has been known since the Pharaonic Middle Kingdom before $\sim 4000$ years ago (Garson and Shalaby, 1976; Elsamani et al., 2001; Klemm et al., 2001) but occurrence of extractable gold at Al Abeidiya area in particular was only first discovered in the mid 1990 by the local natives and then confirmed by the geologist of Rida Mining Company (RMC).

The present investigations coupled with data obtained from the works of $\mathrm{RMC}$, revealed that the area is a potentially significant gold district. Gold deposition exhibits a high degree of variability in form and distribution corresponding to different lithological, geochemical and structural controlling aspects. Therefore, gold mineralization occurs as gold-sulfide, gold-quartz vein and gold-ferruginous quartzite formations hosted by intensely sheared and hydrothermally altered granitoid rocks, the surrounding greenschist-facies island arc assemblages and the ophiolitic sequences. Only the first two types are studied and described in this study as the other type is mostly lies outside the mapped area.

Gold mineralization in the area predominantly occurs in quartz veins, veinlets, sub parallel stringers, systems of stock works and their alteration envelopes. Field relationships and internal deformation features revealed by field and microscopic observations suggest the presence of several types of quartz veins and veinlets within the three generations, formed during different stages of shearing. Only two of these are gold-bearing; vein-disseminated sulphied-gold mineralization of Artoli area and the typical quartz-carbonate vein-type of Umtrambiesh area where as the other barren milky quartz veins are clearly postdate the mineralization. In both vein types, gold is irregularly distributed and usually associated with sulfides. Gold occurrence is detected and studied in tow areas.

The quartz-sulphied disseminated- gold mineralization of Artoli area occurs in the NW part of the area, only few kilometers NE Artoli village. Localization of gold in this part is mainly governed by existence of dilation zones produced by shear deformation in the altered and sulphidized part of quartz veins and wall rock alteration zones. Thus, mineralization range from gold-bearing quartz veins and veinlets, through sub parallel stringers, systems of stock works to small pods and lenses of sulphide disseminations. It is predominantly hosted by sheared intermediate to acidic, calk-alkaline plutonic igneous rocks, mostly granodiorites and quartz-diorites. The Au-bearing quartz veins are generally deformed; fractured, folded, dragged and mostly found along a N-S to NNW-trending shear zone. The veins are generally of variable sizes with longitudinal dimensions reaching to $>100 \mathrm{~m}$ and widths varying from few $\mathrm{cm}$ to $<1.5 \mathrm{~m}$. Field indications for the occurrence of this type, in addition to the quartz veins, are reflected on surface exposures as extensive oxidation zones (stains of Fe-hydroxides and malachite), altered cracks in country rocks and visible fine-grained sulphide minerals in some host rocks.

Gold is preferentially encountered associated with $\mathrm{Fe}$ oxides/hydroxides replacing sulphides as dissemi-nation pseudomorhps slightly enriched in $\mathrm{Cu}$ following structures and filling cracks in the country rocks. An appreciable amount also enriched as minute submicroscopic grains (too fine for visual identification) and some visible grains in quartz veins.

The vein-type mineralization of Umtrambiesh area occurs $7 \mathrm{~km}$ east of Al Abeidiya town in the SE sector of the study area just opposite to the biggest bend of Wadi Dar Tawoi. The type of mineralization in this area is mainly in the form of auriferous quartz veins (and their lateral digitations) which are always aligned along a N-S trending shear zone. The mineralization occupies a junction zone between rocks of contrasting competency comprising granodiorite, low-grade schists and abutting basic/ ultrabasic rocks and controlled by the N-S striking Umtrambiesh faults (Fig. 7). The veins are irregular, fractured, locally folded and affected by drag and boudinage shown by pinch-and swell structures. They are generally thin $0.5-1.5 \mathrm{~m}$ in width and extend in a discontinuous manner for varying depth and length that may reach up to $200 \mathrm{~m}$ length (natives locally mined to $>50 \mathrm{~m}$ depth), their formation is probably attributed to a repeated fracturing during brittle-ductile shear events as demonstrated by occurrence of lineated minerals along vein margins. A number of brecciated and crosscutting net works of veinlets, stringers variably developed along the main quartz veins in addition to a wide alteration zones that enclose disseminated ore.

The overall morphology of the ore veins tends to be tabular, linear or lens-shaped with the minimum dimensions orthogonal to the shear planes. Gold occurs 
as pure, free intergranular and frequently minute, visible gold grains of pale yellow colour or may occur dispersed as tiny invisible grains associated with sulphides, though; this type seems to be quantitatively of less importance compared to the first one.

Structural geometry and textural features indicate that mineralization in both types have been controlled by some structural patterns. The occurrence of the main oreshoots within the NW-SE and N-S-trending shear zone parallel to D3structures and their tabular geometry represent evidence for this structural control on gold distribution. Adjacent to the mineralized quartz veins, the host rocks are bleached and brecciated, in addition, there are elongated asymmetric biotite and feldspar prophyroblasts and rootless microfolds, indicate mineralization controlled by brittle-ductile deformation that prevailed during the formation of this shear zone (Fig. 6b).

Ore mineralogy: Representative samples of both goldbearing generations of quartz veins and alteration zones were collected including samples from the diamond-drilled holes of RMC at Umtrambiesh area. Microscopic works as well as sulfide and gold analyses were performed on 21 polished and thin sections. The resultant data combined with field observations revealed that gold occurs in native form, as disseminations associated with sulfides in quartz veins, stringers, lenses or as irregular blebs and globules dispersed in pervasively sericitized and chloritized wall rock alteration zones.
In the disseminated-type mineralization at Artoli area, gold found usually as invisible disseminated grains in quartz veins with sulphides (only detected in geochemical analysis), though visible fine to medium-grained native gold ( $\sim 25-5 \mathrm{~mm})$ or even rounded grains, flakes or nuggets in streams are also common. Gold content in the quartz veins ranges between $0.0024-2.6 \mathrm{~g} \mathrm{ton}^{-1}$ where as in the country rock between $0.001-0.8 \mathrm{~g} \mathrm{ton}^{-1}$.

Arsenopyrite, sphalerite, pyrite and malachite are the main sulfide phases, whereas galena, pyrrhotite and chalcocite are minor components. These sulphide minerals are relatively minor components of the quartz veinlets but are more abundant as disseminations in the alteration zones. They occur mostly as medium to coarse-grained crystals $(>0.5 \mathrm{~mm}$ ) forming interlocking aggregates where as in deformed veins are always fine-grained $(<0.2 \mathrm{~mm})$ or only disseminations, particularly abundant at the contacts between the quartz veins and the wall rocks. In the typical vein-type mineralization at Umtrambiesh area, pure, free and minute gold grains occur in the quartz veins with content ranging between 0.01-24.0 $\mathrm{g} \mathrm{ton}^{-1}$ and dispersed, tiny invisible grains associated with sulphides in the alteration zones with content ranging between 0.001-8.5 $\mathrm{g} \mathrm{ton}^{-1}$. The most abundant sulfide spices are pyrite, arsenopyrite beside minor sphalerite, chalcopyrite, galena and rare malachite.

Pyrite constitutes the dominant sulphide phase in both types and occurs as medium to coarse-grained crystals up to $5 \mathrm{~mm}$ in size, mostly euhedral to subhedral or frequently with cubic form (Fig. 8). Arsenopyrite is the

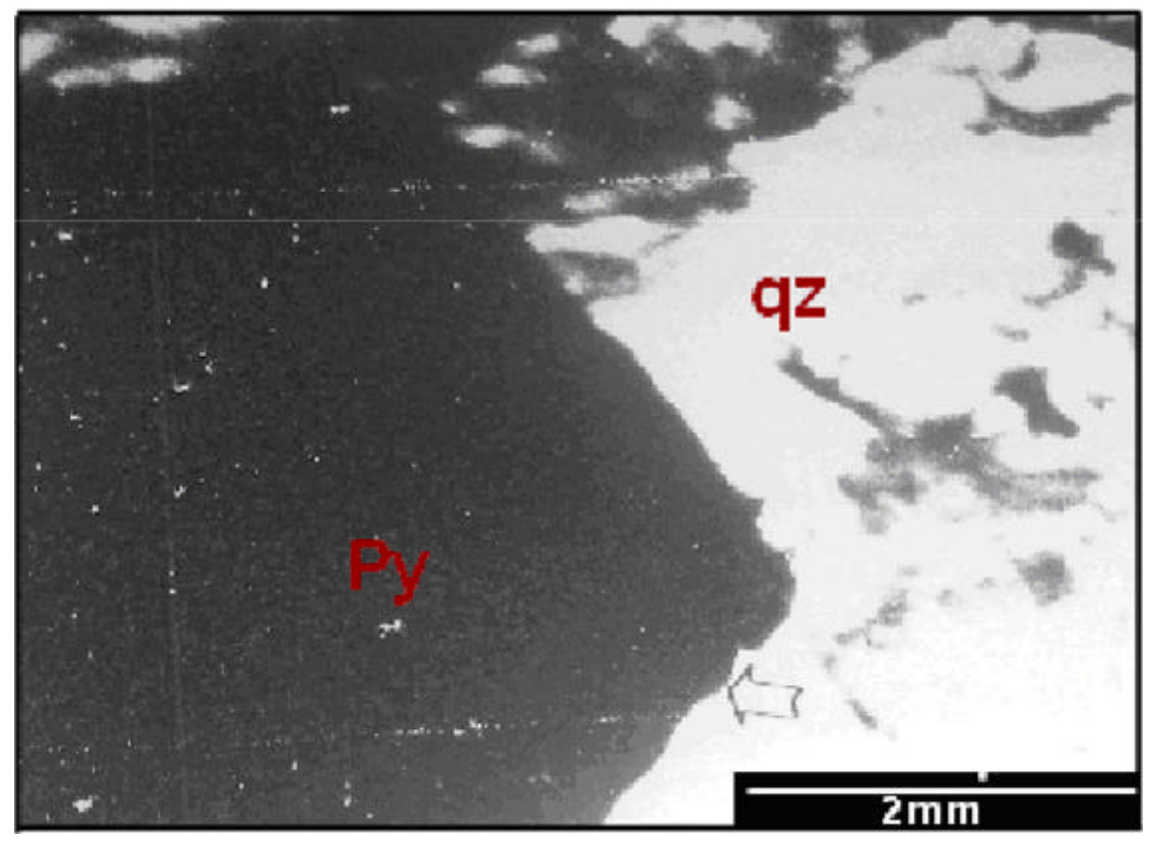

Fig. 8: Reflected-light photomicrograph showing euhedra crystal of pyrite associated with quartz grains and alteration products. $\mathrm{qz}=$ quartz and $\mathrm{Py}=$ pyrite 
second dominant sulfide occurs as small homogenous grains mostly within the disseminated-type mineralization at Artoli area. Sphalerite forms subhedral to irregularly shaped isolated crystals in quartz, some times containing inclusions of other suphides.

Common gangue minerals include quartz and carbonates (ankerite, siderite and calcite) in addition to secondary Fe-oxides, chlorite, white mica and minor talc and clay minerals in the weathered portions of the veins and their wall rocks. The quartz is formed of coarse to medium interlocking crystals with sutured borders and wavy extinction.

Multi-element analyses carried out on various samples encompassing channel and core samples from trenches and diamond drill holes (dug by RMC) and scattered random surface samples from allover the area. The results revealed that gold mineralization has taken place in association with minor distinct suite of elements including; $\mathrm{Cu}, \mathrm{Zn}, \mathrm{Mo}$ and $\mathrm{Ag}$ in Artoli area and $\mathrm{Cu}, \mathrm{Zn}$ and As in Umtrambiesh area.

There is no clear relationship detected between $\mathrm{Au}$ and the base metals except the close spatial association between $\mathrm{Au}$ and $\mathrm{Cu}$ (Table 1 and 2). Lead and $\mathrm{Zn}$ values tend to be high in the Au-rich metavolcanic samples. Cu contents are relatively high in the alteration part of the quartz veins and may be also elevated in the country rock in close proximity to them.

Wall rock alteration: Field observations and microscopic micro-structural investigations show that the rocks adjacent to the mineralization in the study area locally suffered pervasive and/or selective alterations and mineralization which are not limited to only the auriferous quartz-vein ore body but occur also in the wall rocks.

Around the gold-bearing quartz veins at Umtrambiesh area, there developed few meters up to $>10 \mathrm{~m}$ wide halo of bleached rocks. The alteration types encountered include; sericitisation, carbonatisation, chloritisation, pyritazation and silicification (Fig. 9), within which both selective (Alteration of hornblende to biotite and chlorite) and pervasive (conversion of the whole rock to serisite, chlorite and talc-schists) alterations exist. The effects of alteration seem to be dependant to some degree on the nature of the host rock being best developed around shistosed wall rocks. Distinct mineralogical changes, e.g., the replacement of feldspars by sericite and the development of epidote at the expense of biotite and hornblende shown around the hydrothermal Au-bearing quartz veins suggest metasomatic alteration.

Petrographic and micro-structural analyses indicate a gradual transformation of the host rock from apparently undeformed rock through an intermediate zone to the finegrained extensively altered zone forming a zoned hydrothermal alteration halo (Table 3 ). The halo can be distinguished into three alteration zones including an inner quartz-sulphide-sericite zone an intermediate quartz -sericite-chlorite zone and an outer chlorite-carbonate zone. Generally, the intensity of quartz veinlets and gold enrichment increases towards the inner alteration zones.

At Artoli area, alteration zones consisting of bleached rock and abundant disseminated Fe-sulphides developed in the host rocks around the auriferous quartz veins exemplified by saussuritisation and kaolinitisation of the feldspars and chloritisation and carbonatisation of the mafic phases. When the host rock is exclusively plutonic, wall rock alteration is represented by chloritisation, sericitisation, sulphidization, epidotization, silicification, kaolinization and feldsparthization.

Chemically the alteration is indicated by higher $\mathrm{Fe}_{2} \mathrm{O}_{3}$, $\mathrm{K}_{2} \mathrm{O}, \mathrm{P}_{2} \mathrm{O}_{5}, \mathrm{MnO}, \mathrm{TiO}_{2}$ and $\mathrm{Na}_{2} \mathrm{O}$ and lower $\mathrm{SiO}_{2}, \mathrm{MgO}$ and $\mathrm{CaO}$ contents in the hydrothermally altered wall rocks compared to the least altered rocks (Table 3 ). Loss on ignition (LOI) is considerably higher in samples displaying intense alteration (Table 3 ) which resulted in abundance of alteration minerals such as chlorite, carbonate and pyrite indicating addition of volatiles into sheared parent rock. The high $\mathrm{K}_{2} \mathrm{O}$ and $\mathrm{Na}_{2} \mathrm{O}$ is expressed mineralogically in the occurrences of biotite, $\mathrm{K}$-feldspar and muscovite and the gains in $\mathrm{Fe}_{2} \mathrm{O}_{3}, \mathrm{MnO}$ and $\mathrm{TiO}_{2}$ content are mainly due to the formation of Ferich epidote, magnetite, ilmenite and sphene. The low $\mathrm{MgO}$ and $\mathrm{CaO}$ content in the altered country rocks is clearly elated to their concentrations in quartz-veins.

Timing of the mineralization: Knowledge of timing of mineralization relative to the structural evolution of the host rocks is fundamental to understand the genesis of gold deposits in the area but the lack of age determination and fluid inclusion studies makes it difficult to determine exactly the nature and timing of the mineralizing fluids. Integration of field relations and microscopic microstructural features with correlation through scattered age data from previous research can be utilized to deduce the age relations of different events encompassing gold mineralization in the area, these indicating evidences include:

- Formation of the auriferous veins was later in respect to metamorphism, this is confirmed by the facts that no overprinting of metamorphism on alteration minerals was detected but relics of undigested wall-rock materials are included in sulphides, carbonates and quartz and that the auriferous quartz veins injected sub parallel to the foliations

- The vast majority of productive quartz veins and shear zones lie within and in vicinity of deformed and mineralogically altered granitoids and the surrounding Pan-African volcano-sedimentary assemblage. However, unaltered granitoid rocks and the high-grade gneissic domes did not show positive 
Res. J. Applied Sci., 5 (4): 285-302, 2010

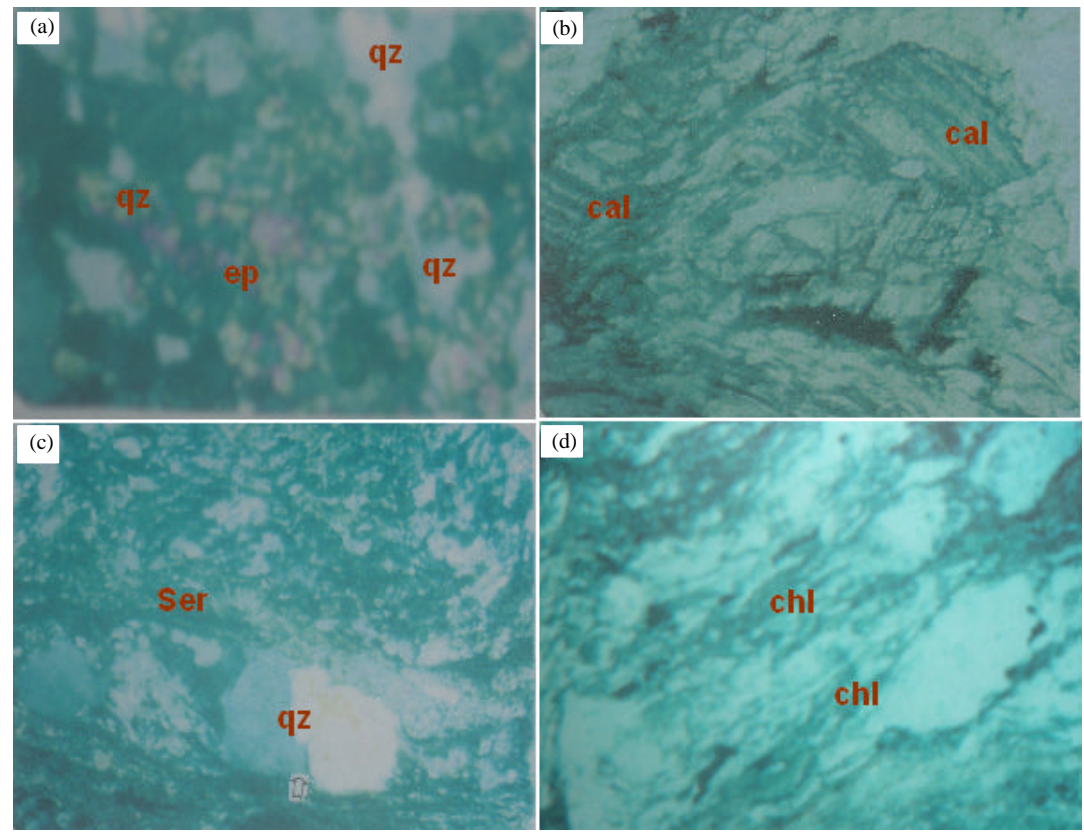

Fig. 9: Thin section micrographs $(0.5 \mathrm{~mm})$ showing the different types of alterations. (a) Propylitic (epidote) alteration observed in actinolite-schist. (Crossed nicols), (b) Carbonatization of chlorite-quartz schist in the mineralized zone (Crossed nicols-UmTrambeish area), (c) Sericite-quartz alteration affecting the quartz-mica schist in the study area (Crossed nicols) and (d) Chloritization affecting the sericite-chlorite schist in the Artoli area (Plane polarized) Abbreviations: $\mathrm{ep}=$ epidote, $\mathrm{cal}=$ calcite, $\mathrm{chl}=$ chlorite, $\mathrm{qz}=$ quartz and $\mathrm{ser}=$ sericite

gold anomalies and the mineralization is transgressive to all other types of basement rocks indicating that these suites were formed in the pre-mineralization time

- Formation of the auriferous veins was related to an episode of intense shearing (late D3) which postdated all older folding and emplacement of the batholithic intrusions (but may have predated the youngest granite intrusions, Vail, 1978). Stained feature of sulphides and inquant prismatic and tabular crystal habits suggest syn-shearing growth

- The latest shearing events related to post-collision movements have commonly distupted the goldbearing veins indicating that the auriferous veins predated later barren ones developed along the latest shear zones. Since the latest shearing postdates the veins this is confirmation of the view expressed by Vail (1978) that the mineralization is older than the post-tectonic magmatism

- Existence of later post-mineralization movements is confirmed by the development of boudinge and minor folding within the mineralized veins and the occurrence of quartz grains that exhibit angular recrystalized nature

Considering all above-mentioned points, it is reasonable to conclude that Au-mineralization postdated metamorphism and batholithic intrusion and was synchronous with the latest stage of shear-induced deformation that post-dated the older events of shearing and faulting. Hence, a time in the Neoproterozoic, Pan-African episode (can be bracketed between 650 and $450 \mathrm{My}$ ) is proposed.

Ore genesis: The mechanism of Au-deposition in the study area was not subjected to comprehensive investigations due to lack of fluid inclusion studies but consideration of geological, structural and textural features, distribution patterns, mineralogical nature and the attendant wall rock alteration were used to decipher the nature of ore gneiss and the following points are considered:

- Mineralization is mainly in the form of auriferousquartz veins which are narrow non-persistent veins defined by nearly sharp vein boundaries, characteristics of shallow level deposits

- Replacement textures characteristics of high temperature deposits are rare, besides, high temperature minerals of typical hypothermal deposits are not detected, in state, pyrite, arsenopyrite sphalerite, galena, carbonates, Fe-oxides and chlorite are recognized 
- Some structural features within the mineral-bearing zones, like the presence of; deformation textures, tensional fractures, subhedreal textured quartz crystals, spider veinlets and fine to medium drusy comb structures indicate emplacement in shear zones by open space filling or true crack sealing

- The alteration mineralogy, replacement textures and destruction of metamorphic fabrics coupled with the symmetrical alteration halos of the shear zones are indicative features that suggest extensive fluid circulation during and/or after fracture development

- As no predictable relation connecting the emplacement of the exposed granitoids with the gold mineralization (are earlier than the shearing a associated with mineralization) coupled with the association of the latter with shear structures it is appropriate to suggest that the ore fluids unlikely emanate from their crystallizing magma. Thus, we are inclined to belief that they might been generated from ascending magma of concealed deep intrusion contemporaneous with the latest shear deformation

- The accessibility, with which gold is leached from the containing rock, appears to be the critical factor in determining the source of the gold despite of its absolute gold content (Viljoen, 1984). Therefore, the low-grade metavolcanic rocks are proposed for source of the gold

Based on the above-mentioned observations, it seems probable to interpret the mineralization as consistent with mesothermal type of hydrothermal deposits. The proposed model that probably explains the host-rock alteration, veining and deposition of gold and sulfides in the area is that:

- In the pre-mineralization stages, deformation associated with mechanical development of shear zones and movement along faults weakened the rocks and created structurally prepared permeable channel ways in the form of fractures and weak zones favorable for hydrothermal fluid mobilization and ore mineral precipitation

- Subduction-related unexposed intrusions delivered the thermal energy and initiated hydrothermal fluids necessary to leach metals from the intermediate and acidic metavolcanics or from nearby mafic/ultramafic rocks and transport them down the pressure gradient towards the surface

- The Au-enriched hydrothermal solutions ascending towards the surface through channel ways were diluted, neutralized and cooled by meteoric water resulting in precipitation of sulfides together with gold

\section{CONCLUSION}

Depending on the above account derived from integrating the field observations and petrographical investigations combined with the geochemical analysis data interpretation it is reasonable to conclude that:

The area under consideration is a regionally metamorphosed terrane entirely underlain by crystalline Proterozioc basement complex and covered locally by Tertiary and Recent sediments. The basement complex is composed predominantly of rocks that have been subjected to low-grade metamorphism, alteration and polydeformation, comprising schistosed metavolcanic rocks mostly of basic, intermediate to acidic calc-alkaline rocks and minor metasediments intruded by voluminous, intermediate to acidic granitoidal batholiths of granodiorite, quartz-diorite and diorite with lesser amount of granite. These batholithic granitoids are medium to high $\mathrm{K}$, calc-alkaline, metaluminous and I-type granitoid suite emplaced as volcanic arc granites above a Noeproterozoic subduction zone during the syn-to late-collision stages of crust evolution. The disclosed overall geological and geochemical characteristics of the metavolcanic and plutonic rocks of the area are similar to those of the Red Sea Hills in Egypt and NE Sudan which indicates that the area is a part of the westernmost Nubian Shield (Lissan and Bakiet, 2010).

The study confirmed the existence of promising deposits of medium to high-grade gold mineralization of varying form and distribution corresponding to different lithological, geochemical and/or structural controlling aspects. The gold mineralization occurs as gold-sulfide, gold-quartz vein and gold-ferruginous quartzite formations in gold-bearing quartz veins, veinlets, sub parallel stringers, systems of stock works (altered and sulphidized part of quartz veins) and wall rock alteration zones hosted predominantly by intensely sheared and hydrothermally altered granitoid rocks and the surrounding greenschist-facies island arc assemblages as well as, the ophiolitic sequences.

Structural geometry and textural features indicate that mineralization was controlled by post-batholithic brittleductile deformation that prevailed during the formation of NW-SE and N-S-trending shear zones parallel to D3structures. The Au-bearing quartz veins are generally deformed; fractured, folded and dragged mostly found along these shear zones.

Gold is preferentially encountered as fine to mediumgrained native gold or as dispersed, tiny invisible grains associated with sulphides in the alteration zones. Pyrite, 
arsenopyrite, sphalerite and chalcopyrite are the main sulfide phases associated with gold, whereas galena, malachite, pyrrhotite and chalcocite are minor components, iron oxide (limonite), carbonates (ankerite, siderite and calcite), chlorite, tourmaline, white mica and minor talcose and clay minerals observed mainly in wall rocks

Field observations of alteration zones and shear structures, as well as petrographic and geochemical data, provided evidence for an extensive wall rock alteration developed around the mineralized zones forming few meters up to tens of meters-wide halo of bleached rocks. The alteration types encountered in the area include; sericitisation, carbonatisation, chloritisation, pyritazation, silicification kaolinitisation and epidotization within which both selective and pervasive types exist. The alteration halo is distinguished, into; an inner quartz-sulphidesericite zone, an intermediate quartz -sericite-chlorite zone and an outer chlorite-carbonate zone.

Integration of field relations and microscopic microstructural features combined with correlation data from previous research concluded that Au-mineralization postdated metamorphism and batholithic intrusion and was synchronous with the latest stage of shear-induced deformation (D3) that post-dated the older events of shearing and faulting.

Based on the host rocks, lode type, alteration assemblage and ore minerals, it seems probable to interpret the mineralization as consistent with mesothermal type of hydrothermal deposits.

The suggested hydrothermal origin of the alteration and mineralization in the area is best understood in terms of post-metamorphic and syn-deformation fluid activity and veining that leached elements from the intermediate and acidic metavolcanics or from the nearby mafic/ultramafic rocks and redeposition by the Auenriched hydrothermal solutions ascending towards the surface through channel ways within sheared zone. The energy sources for the hydrothermal activity that brought about the mineralization is likely provided by unexposed intrusions at deeper levels concentration within the shear zones.

\section{ACKNOWLEDGEMENTS}

This study was conducted at the Department of Geology and Mining, University of Juba and was financially supported by the Dongola University which are sincerely appreciated. The researchers acknowledged Geology department, University of Khartoum, the Geological Research Authority of Sudan (GRAS) for the facilities offered in carrying out petrographic investigation and XRF analyses and the Rida Mining Company, Sudan who covered most of the cost of whole-rock geochemical analyses from Acme Labs. The researchers also acknowledge with great thanks Prof. Dr. He Sheng of China University of Geosciences (Wuhan) for his valuable discussion, comments and constructive remarks on the manuscript. This research would not have been possible without the help and guidance of Adli A/ Majeed, Madani Rajab, of Rida Mining Company, Sudan, Dr. A/haman Ahmed and Dr. Mutasim Adam of Juba University during field mapping.

\section{REFERENCES}

Abdel-Rahman, A.F.M., 1995. Tectonic-magmatic stages of shield evolution: The Pan-African belt in northeast Egypt. Tectonophys, 242: 223-240.

Abdel-Rahman, E.M., 1993. Geochemical and geotectonic controls of the metallogenic evolution of selected ophiolite complexes from the Sudan. Berliner Geowissenschaftliche Abhandlungen, 145: 145-175.

Abdelsalam, M., R.J. Stern, P. Copeland, E.M. Elfaki, B. Elhur and F.M. Ibrahim, 1998. The neoproterozoic keraf suture in NE Sudan: Sinistral transpression along the Eastern margin of West Gondwana. J. Geol., 106: 133-148.

Abdelsalam, M.G. and R.J. Stern, 1996. Sutures and shear zones in the Arabian-Nubian shield. J. Afr. Earth Sci., 23: $289-310$.

Almond, D.C., 1982. New ideas on the geological history of the Basement Complex of NE Sudan. Sudan Note Rec., 59: 106-136.

Aloub, O.A. and Y. Elsamani, 1991. The geology of gold deposits in the Red Sea Hills of the Sudan: PanAfrican tectono-metamorphic models. Bull. GRAS, 39: $30-30$.

Bakheit, A.K., 1991. Geochemical and tectonic control of sulphide-gold mineralization in Ariab mineral district, Red Sea Hills, Sudan. Berlin Technische Univ. (Germany). Fachbereich 16-Bergbau und Geowissenschaften, pp: 161, http:/opensigle.inist.fr/ handle/10068/246699.

Bakhiet, A.K. and G. Matheis, 1993. Gold Productive Volcanogenic Sulphide Mineralization in the Ariab Belt, Red Sea Hills-Sudan: Evidences for Late Proterozoic Seafloor Hydrothermal Systems. In: Geoscientific Research in Northeast Africa, Thorweihe, U. and H. Schandelmeier (Eds.). A.A. Balkema, Rotterdam, pp: 533-540.

Bentor, Y.K., 1985. The crustal evolution of the Arabian Nubian Massif with special reference to the Sinai Peninsula. Precambrian Res., 28: 1-74. 
Botros, N.S., 2004. A new classification of the gold deposits of Egypt. Ore Geol. Rev., 25: 1-37.

Cottard, F., Y. Deschamps, G. Bernadet and Y. El-Samani, 1986. Gold deposits of Ariab area. BRGM Rep. No. 86 SDN 110, Khartoum, pp: 55.

E1-Boushi, I.M., 1972. Geology of the gebeit gold mine, democratic republic of the Sudan Econ. Geol., 67: 481-486.

El-Rabaa, S.M., 1976. The geology of the late precambrian early palaeozoic sediments in Sudan. Proceeding of the 3rd Conference on African Geological Society, Abs. Khartoum.

El-Shazly, E.M., 1957. Classification of Egyptian mineral deposits. Egypt. J. Geol., 1: 1-20.

Elsamani, Y., A. Almuslem and M. El-Tokhi, 2001. Geology and geotectonic classification of Pan-African gold mineralizations in the red sea hills, Sudan. Int. Geol. Rev., 43: 1117-1128.

Garson, M.S. and I. Shalaby, 1976. Precambrian-lower palaeozoic plate tectonics and metallogenesis in the Red Sea region. Geol. Assoc. Can. Spec. Pap., 14: 573-596.

Gass, I.G., 1981. Pan-African (Upper Proterozoic) Plate Tectonics of the Arabian-Nubian Shield. In: Precambrian Plate Tectonics, Kroner, A. (Ed.). Elsevier, Amsterdam, pp: 387-405.

Irvine, T.N. and W.R.A. Barager, 1971. A guide to the chemical classification of the common volcanic rocks. Can. J. Earth Sci., 8: 523-548.

Kennedy, W.Q., 1964. The structural differentiation of Africa in the Pan-African (+500 my) episode. Univ. Leeds Res. Inst. Afr. Geol. 8th Ann. Rep., 8: 48-49.

Klemm, D.D., R. Klemm and A. Murr, 2001. Gold of the Pharaohs-6000 years of gold mining in Egypt and Nubia. J. Afr. Earth Sci., 33: 643-659.

Kroner, A., 1984. Late Precambrian Plate Tectonics and Orogeny: A Need to Redefine the Term Pan-African. In: African Geology, Klerkx, J. and J. Mishot (Eds.). Geological Society, Tervuren, Belgium, pp: 23-28.

Kroner, A., R. Greiling, T. Reischmann, I.M. Hussein, R.J. Stern, S. Durr and M. Zimmer, 1987. Pan-African crustal evolution in the segment in the northern Africa. Am. Geophysical Union Geodynamics Series, 17: 235-257.

Kuster, D. and J.P. Liegeois, 2001. Sr, Nd isotopes and geochemistry of the Bayuda Desert high-grade metamorphic basement (Sudan): An early Pan-African oceanic convergent margin, not the edge of the East Saharan ghost craton. Prec. Res., 109: 1-23.
Lissan, N.H. and A.K. Bakiet, 2010. The geology and geochemistry of metavolcanic rocks of artoli area, berber province, northern Sudan: An implication for petrogenetic and tectonic setting. J. Am. Sci., 6: 1-13. Mageed, A.A., 1998. Sudan Industrial Minerals and Rocks. Centre for Strategic Studies, Khartoum, Sudan, pp: 553.

Muller, D., L. Franz, P.M. Herzig and S. Hunt, 2001. Potassic igneous rocks from the vicinity of epithermal gold mineralization, Lihir Island, Papua new Guinea. Lithos, 57: 163-186.

Omer, M.K., 1983. The Geology of the Nubian Sandstone Formation in Sudan, Stratigraphy, Sedimentation Dynamics, Diagenesis. Geological and Mineral Resources Department, Khartoum, Sudan, pp: 227.

Pearce, J.A., N.B.W. Harris and A.G. Tindle, 1984. Trace element discrimination diagrams for the tectonic interpretation of granitic rocks. J. Petrol., 25: 956-983.

Pohl, W., 1988. Precambrian Metallogeny of NE-Africa. In: The Pan-African belt of NE Africa and Adjacent Areas, El-Gaby, S. and R.O. Greiling (Eds.). Earth Evolution Science, Wiesbaden, pp: 319-341.

Shand, S.J., 1927. Eruptive Rocks: Their Genesis, Composition, Classification and Their Relation to Ore-deposits. Murby, London, pp: 360.

Stern, R.J. and A. Kroner, 1993. Geochronologic and isotopic constraints on Late Precambrian crustal evolution in NE Sudan. J. Geol., 101: 555-574.

Stoeser, D.B. and V.E. Camp, 1985. Pan-African microplate accretion of the Arabian shield. Geol. Soc. Am. Bull., 96: $817-826$.

Vail, J.R., 1978. Outinc of the geology and mineral deposits of the democratic republic of Sudan and adjacent areas: Overseas. Geol. Mineral Resour., 49: 68-68.

Vail, J.R., 1983. Pan-African crustal accretion in north-east Africa. J. Afr. Earth Sci., 1: 285-294.

Vail, J.R., 1985. Pan-African (Late Precambrian) tectonic terrains and the reconstruction of the Arabian-Nubian Shield. Geology, 13: 839-842.

Viljoen, M.J., 1984. Archaean Gold Mineralization and Komatiites in Southern Africa. In: Gold 82, The Geology, Geochemistry and Genesis of Gold Deposits, Foster, R.P. (Ed.). A.A. Balkema Publication, Rotterdam, pp: 595-627.

Whalen, J.B., K.L. Currie and B.W. Chappell, 1987. A-type granites: Geochemical characteristics, discrimination and petrogenesis. Contrib. Mineral. Petrol., 95: 407-419. 